\title{
PENGARUH PENGGUNAAN LIMBAH CAIRAN RUMEN DAN LUMPUR GAMBUT SEBAGAI STARTER DALAM PROSES FERMENTASI METANOGENIK
}

\author{
INFLUENCE OF THE USE RUMEN LIQUID WASTE AND PEAT MUD AS STARTER ON \\ METHANOGENIC FERMENTATION PROCESSES
}

\author{
Kunty Novi Gamayanti*, Ambar Pertiwiningrum, dan Lies Mira Yusiati \\ Fakultas Peternakan, Universitas Gadjah Mada, Jl. Fauna No. 3, Bulaksumur, Yogyakarta, 55281
}

\section{INTISARI}

Penelitian bertujuan untuk mengetahui pembentukan biogas, gas metan, dan aktivitas enzim pada fermentasi anaerobik feses sapi yang ditambahkan limbah cairan rumen dan lumpur gambut mempercepat proses fermentasi dan meningkatkan produksi biogas. Penelitian terdiri dari 3 macam perlakuan, yaitu tanpa inokulum, dengan penambahan inokulum limbah cairan rumen sebesar 25\%, dan dengan penambahan inokulum lumpur gambut sebesar $25 \%$. Setiap perlakuan terdiri dari 3 ulangan, dengan pengamatan 0; 10; 20; 30; dan 40 hari. Pada akhir fermentasi dilakukan uji gas metan. Data yang diperoleh dianalisis variansi menggunakan pola split plot untuk pengamatan pengukuran volume biogas, konsentrasi gas metan, produksi metan, pengamatan temperatur sludge digester dan derajat keasaman ( $\mathrm{pH}$ ). Hasil penelitian menunjukkan bahwa nilai $\mathrm{pH}$ dan suhu menunjukkan perbedaan yang tidak nyata. Volume biogas menunjukkan hasil yang nyata $(\mathrm{P}<0,05)$ dengan nilai rata sebesar 228,67 ml tanpa inokulum, $229,65 \mathrm{ml}$ dengan inokulum cairan rumen, $358,25 \mathrm{ml}$ dengan inokulum lumpur gambut dan sampai hari ke-40 mengalami kenaikan. Nilai kadar metan menunjukkan hasil yang nyata $(\mathrm{P}<0,05)$ dengan nilai rata sebesar $35,91 \%$ tanpa inokulum, 35,74\% dengan inokulum cairan rumen, 38,52\% dengan inokulum lumpur gambut dan sampai hari ke-40 mengalami kenaikan. Produksi metan yang dihasilkan menunjukkan perbedaan yang nyata $(\mathrm{P}<0,05)$ dengan nilai rata sebesar $91,15 \mathrm{ml}$ tanpa inokulum, 119,36 ml dengan inokulum cairan rumen, 150,62 ml dengan inokulum lumpur gambut dan sampai hari ke40 mengalami kenaikan. Dari hasil penelitian dapat disimpulkan bahwa penambahan limbah cairan rumen dan lumpur aktif gambut hingga $25 \%$ dapat mempercepat proses fermentasi. Perlu adanya penelitian lebih lanjut untuk lama tinggal proses fermentasi di dalam fermentor untuk mengetahui laju maksimal produksi biogas.

(Kata kunci: Biodigester, Bakteri asidogen dan asetogen, Limbah cairan rumen, Lumpur gambut)

\section{ABSTRACT}

This study aims to determine the rate of formation of biogas, to test the potential for methane gas formation and accelerate the anaerobic fermentation process and increase the production of biogas. The study consisted of 3 treatments, i.e. cow feces without the addition of inoculum, cow feces with the addition of rumen fluid waste by $25 \%$ and cow feces with the addition of mud peat by $25 \%$. Each treatment consisted of 3 replications. Observations was done on the $10^{\text {th }}$, the $20^{\text {th }}, 30^{\text {th }}$ and $40^{\text {th }}$. Observations at the end of the fermentation test were conducted on methane. The obtained data were analyzed using split plot analysis calculations for the observation of biogas volume measurements, the concentration of methane gas, sludge digester temperature observations and the degree of acidity (pH). The result showed that $\mathrm{pH}$ and temperature were not significant. The volume of biogas showed significant results $(P<0.05)$ having mean values of $228.67 \mathrm{ml}$ with no inoculums, $229.65 \mathrm{ml}$ for rumen fluid inoculums, $358.25 \mathrm{ml}$ for peat mud inoculums with increasing values until 40 days. The concentration of methane showed significant results $(P<0.05)$ having mean values of $35.91 \%$ with no inoculums, $35.74 \%$ for rumen fluid inoculums, $38.52 \%$ for peat mud inoculums with increasing values until $40^{\text {th }}$ days. The production of methane showed significant results $(P<0.05)$ having mean values of $91.15 \mathrm{ml}$ with no inoculums, $119.36 \mathrm{ml}$ for rumen fluid inoculums, $150.62 \mathrm{ml}$ for peat mud inoculums with increasing values until $40^{\text {th }}$ days. From the results of research it could be concluded that the addition of rumen fluid waste and sludge peat mud up to $25 \%$ could accelerate the process of fermentation. Further research is needed for a longer the fermentation process in fermentor to determine the maximum rate of production of biogas.

(Keywords: Biodigester, Bacteria acidogen and acetogen, Rumen fluid waste, Peat mud)

\footnotetext{
* Korespondensi (corresponding author):

Telp. +6287839116615

E-mail: unthy_maya@yahoo.com
} 


\section{Pendahuluan}

Faktor penting dalam peningkatan produksi gas metan seperti peningkatan proses perombakan serat kasar limbah, optimasi media fermentasi, peningkatan kemampuan mikroba terus diteliti hingga saat ini. Produksi gas metan yang dibentuk sebagai produk akhir perombakan bahan organik tanpa oksigen menjadi nilai utama dalam proses perombakan anaerobik. Energi terbarukan dapat digunakan sebagai pembangkit listrik dan bahan bakar pengganti minyak. Energi biogas didominasi gas metan $60-70 \%$, karbondioksida $40-30 \%$ dan beberapa gas lain dalam jumlah kecil.

Beberapa kelompok mikroorganisme dengan peran berbeda dalam keseluruhan proses bekerja dalam perombakan anaerobik, secara alami terjadi di dalam ekosistem anaerobik seperti dalam sedimen tanah, lahan terendam air, tumpukan manure atau dalam rumen ternak ruminansia (Stams et al., 2003), sehingga dapat digunakan sebagai sumber bakteri metanogenik.

Limbah ternak adalah buangan dari suatu kegiatan usaha peternakan seperti usaha pemeliharaan ternak, rumah potong hewan dan pengolahan produk ternak. Limbah tersebut meliputi limbah padat dan cair seperti feses, urin, sisa makan, embrio, kulit telur, lemak, darah, bulu, kuku, tulang, tanduk, dan isi rumen (Simamora dan Salundik, 2006). Dengan semakin berkembangnya usaha peternakan dan kebutuhan manusia akan hasil ternak maka limbah yang dihasilkan semakin meningkat.

Di dalam rumen ternak ruminansia terdapat mikrobia, yang terdiri dari protozoa, bakteri dan fungi (Sudaryanto, 2002). Salah satu kelompok bakteri yang sangat penting di dalam rumen adalah bakteri selulolitik. Enzim selulase yang dihasilkan bakteri selulolitik mampu memecah selulosa sehingga ternak ruminansia dapat hidup dengan hijauan berkualitas rendah (Arora, 1992). Proses biodegradasi bahan yang mengandung selulosa sangat ditentukan oleh kemampuan mikrobia selulolitik untuk menghasilkan enzim selulase yang mempunyai aktivitas tinggi (Asenjo et al., 1986). Populasi bakteri pada usus besar dan feses ternak ruminansia termasuk golongan spesies bakteri yang juga terdapat di dalam rumen, yaitu termasuk dalam famili Bacteriodes, Fusobacterium, Streptococcus, Eubacterium, Ruminococcus dan Lactobacillus (Omed et al., 2000).

Indonesia mempunyai lahan gambut terbesar nomor empat di dunia. Gambut mengandung selulosa, hemiselulosa serta lignin. Lahan gambut memiliki kandungan bakteri Bacillus sp (Hidayat, 2005). Bacillus merupakan salah satu kelompok bakteri yang mampu mendegradasi selulosa (Lynd et al., 2002). Menurut Cicerone dan Oremland (1988), emisi $\mathrm{CH}_{4}$ saat ini diestimasikan berkisar 400 sampai 600 milyar yang diakibatkan oleh lahan gambut. Gas $\mathrm{CH}_{4}$ merupakan gas yang reaktif dan reaktivitasnya 25-35 kali lebih besar dari gas $\mathrm{CO}_{2}$ per molekul.

Bakteri perombak serat kasar penghasil asetat dan hidrogen merupakan kelompok mikroba penting dalam proses pengolahan limbah secara anaerobik menjadi gas metan karena menyediakan prekursor metan dengan cara bersintrofi dengan bakteri metanogenik. Sebaliknya jika metanogenik tidak ada maka produk akhir asam asetat dan hidrogen akan bersifat toksik bagi asetogenik itu sendiri karena terjadi mekanisme feed back inhibition dalam proses fermentasi bahan organik.

Berdasarkan dari pernyataan di atas maka pemanfaatan limbah cairan rumen ruminansia dan lumpur gambut akan lebih besar nilainya bila digunakan untuk membantu mendegradasi bahan organik secara anaerob, disebabkan limbah cairan rumen dan lumpur gambut mengandung mikroba pendegradasi yang diperkirakan dapat meningkatkan produksi biogas. Penelitian dilakukan untuk meningkatkan efektivitas proses pengolahan limbah organik secara anaerob dengan hasil akhir gas metan melalui penambahan limbah cairan rumen kedalam feses dan penambahan lumpur gambut kedalam feses yang akan diproses secara anaerobik. Penelitian bertujuan untuk mengetahui pembentukan gas metan pada fermentasi anaerobik feses sapi yang ditambah limbah cairan rumen dan lumpur gambut dapat mempercepat proses fermentasi dan meningkatkan produksi biogas.

\section{Materi dan Metode}

\section{Materi}

Feses sapi. Materi penelitian yang digunakan adalah feses sapi Peranakan Ongole (PO) dan silangan Simmental dengan PO (SimPO) segar yang diperoleh dari Laboratorium Ternak Potong, Fakultas Peternakan, Universitas Gadjah Mada. Komposisi kimia feses sapi PO adalah bahan kasar (BK) $16,68 \%$, bahan organik (BO) $77,65 \%$, serat kasar (SK) 24,51\% dengan total ekskresi 5,94 $\mathrm{kg} /$ hari. Rerata kecernaan sapi yang diberikan pakan rumput raja pada sapi PO sebesar BK 70,90\%, BO, $73,50 \%$ dan SK 77,50\% (Yusiati, 2004).

Lumpur gambut. Lumpur gambut yang digunakan sebagai sumber inokulum diperoleh di daerah Rawa Pening, Ambarawa, Jawa Tengah. Lumpur gambut diperoleh pada kedalaman $50 \mathrm{~cm}$ sampai $100 \mathrm{~cm}$. Pengangkutan lumpur gambut dari Rawa Pening ke tempat penelitian adalah setelah lumpur gambut diperoleh lumpur gambut disimpan 
dalam termos yang sudah dalam kondisi suhu sekitar $45^{\circ} \mathrm{C}$.

Limbah cairan rumen. Limbah cairan rumen yang digunakan sebagai sumber inokulum diperoleh dari Rumah Pemotongan Hewan (RPH) di daerah Jalan Kaliurang Km 7, Sleman, Yogyakarta. Jenis sapi yang dipotong adalah sapi SimPO. Pengambilan cairan rumen dilakukan pukul 01.00 sampai 02.30 WIB setelah rumen dikeluarkan dari sapi saat dipotong dan isi rumen langsung disimpan dalam termos yang sudah dalam kondisi suhu sekitar $45^{\circ} \mathrm{C}$.

Alat digester. Alat yang digunakan dalam penelitian adalah 15 unit biodigester, termometer, higrometer, kertas indikator universal $\mathrm{pH}$ 0-14, Merck untuk mengukur pH substrat, alat pengukur volume biogas. Fermentor yang digunakan berupa botol kaca dengan volume botol $2.5 \mathrm{~L}$. Rangkaian alat yang digunakan dalam penelitian disajikan pada gambar reaktor anaerobik Batch culture.

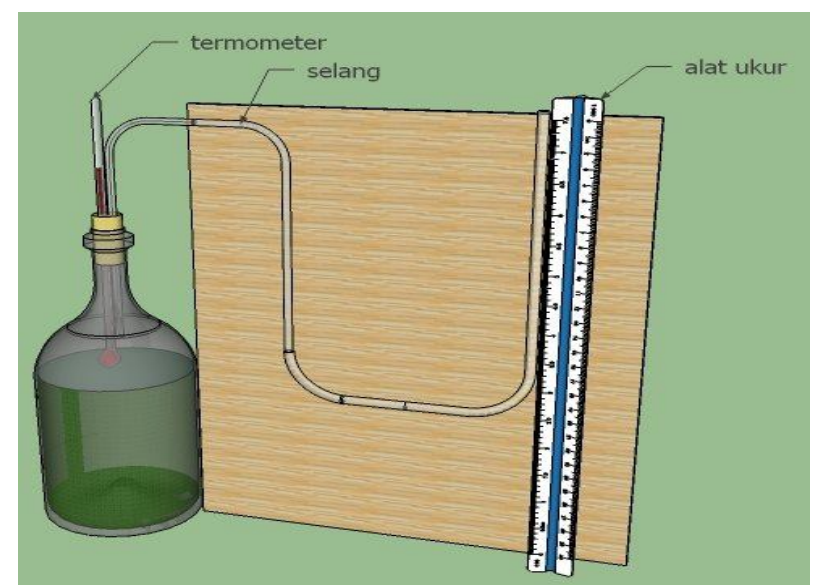

Gambar reaktor anaerobik Batch culture (Batch culture anaerobic of reactor).

Reaktor anaerobik Batch culture dirancang untuk mendapatkan data volume gas, temperatur, dan $\mathrm{pH}$. Volume gas diukur dengan mengamati perubahan volume air pada selang, temperatur dapat diamati secara langsung dengan thermometer yang terpasang di dalam minibiodigester, $\mathrm{pH}$ diukur dengan $\mathrm{pH}$ universal dengan mengambil sedikit sampel melalui selang pengeluaran sampel. Selang pengeluaran sampel digunakan untuk mengambil sampel gas yang akan diukur konsentrasi gas metan.

\section{Metode}

Penelitian berlangsung dalam 3 tahap, yaitu tahap pertama preparasi substrat untuk pembuatan biogas, tahap kedua yaitu pembuatan biogas, dan tahap ketiga yaitu analisis sampel.

Preparasi substrat. Substrat terdiri dari feses, cairan rumen, lumpur gambut sebelum di- lakukan untuk memproduksi biogas. Digester yang digunakan mempunyai jumlah total isian 2,5 liter dan volume pengisian $80 \%$ dari volume total yaitu 2 liter. Bahan substrat yang dimasukkan memiliki perbandingan 1:2 v/v. Pada perlakuan tanpa inokulum terdiri dari $665 \mathrm{ml}$ feses segar dan 1335 $\mathrm{ml}$ air. Pada perlakuan penambahan inokulum 25\% terdiri dari $499 \mathrm{ml}$ feses segar, $166 \mathrm{ml}$ limbah cairan rumen dan $1335 \mathrm{ml}$ air. Pada perlakuan penambahan inokulum 25\% terdiri dari $499 \mathrm{ml}$ feses segar, $166 \mathrm{ml}$ lumpur gambut dan $1335 \mathrm{ml}$ air. Pencampuran bahan dilakukan dengan cara meremas-remas bahan yang menggumpal sampai hancur sehingga bahan tercampur secara homogen.

Pembuatan biogas. Percobaan dilakukan dengan 3 perlakuan dan dilakukan pengulangan sebanyak 3 kali. Pengisian substrat ke dalam digester dilakukan satu kali, tidak dilakukan secara continue. Substrat dasar dihancurkan terlebih dahulu dengan diremas-remas dengan dicampur dengan air agar lebih mudah hancur sehingga substrat dalam digester akan homogen. Digester diletakkan pada suhu lingkungan selama 10 hari sampai 40 hari, dikarenakan awal pembentukan gas pertama pada hari ke-10 dan diharapkan pada hari ke-40 sudah menghasilkan produksi gas yang optimal. Selama pembuatan biogas, dilakukan pengamatan volume gas yang terbentuk, pengukuran temperatur digester, temperatur lingkungan serta $\mathrm{pH}$ setiap pukul 10.00 WIB dan pada hari ke-10 diambil sampel gas untuk analisis kadar metan. Pengambilan sampel diulang pada pada hari ke-20, 30, dan 40.

Analisis sampel. Sampel yang dianalisis yaitu volume biogas, kadar gas metan, dan produksi metan. Volume biogas yang terbentuk diukur dengan mengamati perubahan volume air pada buret (asumsi: biogas yang dihasilkan sama dengan perubahan air yang didorong gas dalam selang). Selang yang digunakan berdiameter $0,5 \mathrm{~cm}$ dengan tinggi $50 \mathrm{~cm}$. Volume gas dihitung dengan menggunakan rumus: $\mathrm{V}=\pi \times \mathrm{rr}^{2} \times \mathrm{t}$

Keterangan:

$\mathrm{V}=$ volume gas berbentuk silinder

$\pi=3,14$

$\mathrm{r}^{2}=$ jari-jari lingkaran

$\mathrm{t}=$ tinggi silinder

Kadar gas metan dianalisis dengan menggunakan metode Gas Chromatography. Preparasi sampel dilakukan dengan menggunakan shirink 10 ml yang disuntikkan ke dalam selang keluar gas dan kemudian segera dimasukkan ke dalam vacutainer $10 \mathrm{ml}$ yang sudah dalam keadaan vacuum, kemudian dimasukkan ke dalam alat Gas Chromatography. 
Tabel 1. Komposisi substrat digester untuk produksi biogas (composition of digester substrate for biogas production)

\begin{tabular}{lllll}
\hline \hline \multicolumn{1}{c}{ Perlakuan (treatment) } & \multicolumn{4}{c}{ Hari (days) } \\
\cline { 2 - 5 } & 10 & 20 & 30 & 40 \\
\hline Tanpa inokulum (without inoculum) & $\mathrm{X}$ & $\mathrm{X}$ & $\mathrm{X}$ & $\mathrm{X}$ \\
Inokulum cairan rumen (with inoculum of rumen liquid) & $\mathrm{X}$ & $\mathrm{X}$ & $\mathrm{X}$ & $\mathrm{X}$ \\
Inokulum lumpur gambut 25\% (with inoculum of peat mud 25\%) & $\mathrm{X}$ & $\mathrm{X}$ & $\mathrm{X}$ & $\mathrm{X}$ \\
\hline
\end{tabular}

Produksi metan diperoleh dengan cara menghitung jumlah produksi gas yang dihasilkan dengan hasil kadar metan berdasarkan jumlah produksi gas (z) dan kadar metan (y), sehingga diperoleh perhitungan dengan rumus:

$$
\text { Produksi metan }=\frac{\mathrm{y}}{100} \times \mathrm{z}
$$

Keterangan:

y: nilai kadar metan

z: jumlah vol gas yang dihasilkan

\section{Analisis data}

Pengolahan data menggunakan analisis statistik pola split untuk pengamatan pengukuran volume biogas, konsentrasi gas metan, produksi metan, pengamatan temperatur sludge digester dan derajat keasaman $(\mathrm{pH})$. Hasil analisis apabila signifikan akan dilanjutkan uji analisis variansi pola searah (One-way) Anova kemudian dilanjutkan dengan Duncan's New Multiple Range Test (DMRT) (Astuti, 1981).

\section{Hasil dan Pembahasan}

\section{Temperatur biogas}

Rata-rata temperatur biogas pada tiap digester dengan beda perlakuan dan pengamatan setiap hari, masing-masing disajikan pada Tabel 2.

Temperatur dalam tiap reaktor berada pada kisaran $27,33^{\circ} \mathrm{C}$. Suhu dalam reaktor cenderung mengalami fluktuasi dan cenderung turun. Fluktuasi ini disebabkan karena pada proses dekomposisi bahan organik menghasilkan air yang dapat menurunkan suhu, sedangkan kenaikan suhu dikarenakan proses dekomposisi bahan organik bersifat eksoterm. Meningkatnya suhu menandakan bahwa telah terjadi proses dekomposisi bahan organik. Penguraian bahan organik akan menghasilkan gas metan, CO2, sejumlah trace gas, dan panas. Temperatur merupakan faktor lingkungan yang penting dalam akitivitas mikroorganisme pada proses biologis secara anaerob. Oleh karena itu hasil pengukuran terhadap temperatur, cenderung mengikuti temperatur lingkungan berkisar antara $27^{\circ} \mathrm{C}$ pagi hari dan $29^{\circ} \mathrm{C}$ sore hari. Kondisi lingkungan termasuk dalam kondisi mesofilik. Menurut Yuwono (2006), suhu di daerah tropis berkisar 25$35^{\circ} \mathrm{C}$ sudah cukup bagus. Chae et al. (2007) menyatakan bahwa pada suhu $25^{\circ} \mathrm{C}$ metan yang dihasilkan hanya $82,6 \%$ dari produksi pada suhu $35^{\circ} \mathrm{C}$. Suhu isian digester berpengaruh terhadap perkembangan bakteri dalam proses pencernaan feses.

\section{Derajat keasaman (pH) biogas}

Rata-rata $\mathrm{pH}$ biogas pada tiap digester dengan beda perlakuan dan pengamatan setiap hari, masingmasing disajikan pada Tabel 3.

Data analisis variansi menunjukkan hasil yang tidak nyata pada beda perlakuan, nilai $\mathrm{pH}$ dengan penambahan inokulum lumpur gambut memiliki nilai rerata yang rendah yaitu 6,73 sedangkan penambahan inokulum cairan rumen tidak berbeda nyata dengan tanpa inokulum yaitu 6,77 . Perubahan pH yang terjadi menunjukkan pertumbuhan bakteri yang terjadi adalah bakteri pembentuk metan karena produksi metan terjadi pada kondisi $\mathrm{pH}$ netral. Hidayat (2005) menyatakan bahwa tanah gambut berada pada lingkungan yang asam yaitu dengan $\mathrm{pH}$ 4,5. Blakely dan Bade (1991) menyatakan bahwa $\mathrm{pH}$ rumen yaitu antara 6,0 sampai 6,8 . Nilai $\mathrm{pH}$ merupakan salah satu faktor lingkungan yang berperan penting dalam aktivitas mikroorganisme dalam proses anaerobik. Untuk pembentukan metan terjadi saat nilai $\mathrm{pH}$ berada pada rentang $\mathrm{pH}$ netral, yakni 6,8 sampai 7,2 (Eckenfelder, 2000). Menurut Gallert dan Winter (1999), penurunan $\mathrm{pH}$ setelah hari ke-0 yang menggambarkan terbentuknya tahap fermentasi/asidogenesis yang menyebabkan $\mathrm{pH}$ lingkungan menjadi rendah. Perubahan kondisi lingkungan akan mempengaruhi pertumbuhan dan kehidupan bakteri awal, sehingga bakteri yang tidak mampu beradaptasi terhadap kondisi tersebut akan mengalami kematian karena kondisi lingkungan yang tidak mendukung proses metabolisme bakteri tersebut.

\section{Volume biogas}

Rata-rata volume biogas pada tiap digester dengan beda perlakuan dan pengamatan setiap hari, masing-masing disajikan pada Tabel 4.

Data analisis variansi menunjukkan hasil yang nyata $(\mathrm{P}<0,05)$ pada beda perlakuan dan beda waktu fermentasi. Ketiga perlakuan penambahan inokulum lumpur gambut memiliki volume gas lebih tinggi yaitu $358,25 \mathrm{ml}$ daripada dengan 
Tabel 2. Temperatur pada produksi biogas $\left({ }^{0} \mathrm{C}\right)$ (temperature on biogas production $\left({ }^{0} \mathrm{C}\right)$ )

\begin{tabular}{lcccccc}
\hline \multicolumn{1}{c}{ Perlakuan (treatment) } & $\begin{array}{c}\text {-hari } \\
(0 \text { days })\end{array}$ & $\begin{array}{c}\text { 10-hari } \\
(10 \text { days })\end{array}$ & $\begin{array}{c}20 \text {-hari } \\
(20 \text { days })\end{array}$ & $\begin{array}{c}30 \text {-hari } \\
(30 \text { days })\end{array}$ & $\begin{array}{c}40 \text {-hari } \\
(40 \text { days })\end{array}$ & $\begin{array}{c}\text { Rerata } \\
(\text { average })^{\mathrm{ns}}\end{array}$ \\
\hline $\begin{array}{l}\text { Tanpa inokulum (without inoculum) } \\
\begin{array}{l}\text { Inokulum cairan rumen (with inoculum of } \\
\text { rumen liquid) }\end{array}\end{array}$ & 27,00 & 27,33 & 27,67 & 27,00 & 27,33 & 27,26 \\
$\begin{array}{l}\text { Inokulum lumpur gambut (with inoculum } \\
\text { of peat mud) }\end{array}$ & 27,33 & 27,33 & 27,33 & 27,67 & 27,40 \\
\hline Rerata (average) & 27,33 & 27,67 & 26,83 & 27,00 & 27,16 \\
ns & 27,11 & 27,33 & 27,56 & 27,05 & 27,33 & \\
non significant. & & & & &
\end{tabular}

Tabel 3. Nilai $\mathrm{pH}$ pada produksi biogas ( $p H$ value on biogas production)

\begin{tabular}{|c|c|c|c|c|c|c|}
\hline Perlakuan (treatment) & $\begin{array}{c}0 \text {-hari } \\
(0 \text { days })\end{array}$ & $\begin{array}{l}\text { 10-hari } \\
(10 \text { days })\end{array}$ & $\begin{array}{c}\text { 20-hari } \\
(20 \text { days })\end{array}$ & $\begin{array}{c}\text { 30-hari } \\
(30 \text { days })\end{array}$ & $\begin{array}{l}\text { 40-hari } \\
(40 \text { days })\end{array}$ & $\begin{array}{c}\text { Rerata } \\
(\text { average })^{\mathrm{ns}}\end{array}$ \\
\hline Tanpa inokulum (without inoculum) & 7,0 & 6,83 & 6,83 & 6,67 & 6,50 & 6,77 \\
\hline $\begin{array}{l}\text { Inokulum cairan rumen (with inoculum of } \\
\text { rumen liquid) }\end{array}$ & 7,0 & 6,83 & 6,67 & 6,67 & 6,67 & 6,77 \\
\hline $\begin{array}{l}\text { Inokulum lumpur gambut (with inoculum } \\
\text { of peat mud) }\end{array}$ & 7,0 & 6,67 & 6,83 & 6,67 & 6,50 & 6,73 \\
\hline Rerata (average) & $7,0^{\mathrm{a}}$ & $6,78^{\mathrm{b}}$ & $6,78^{\mathrm{a}}$ & $6,67^{\mathrm{a}}$ & $6,56^{\mathrm{a}}$ & \\
\hline
\end{tabular}

Tabel 4. Volume gas pada produksi biogas (ml) (gas volume on biogás production (ml))

\begin{tabular}{|c|c|c|c|c|c|}
\hline Perlakuan (treatment) & $\begin{array}{l}\text { 10-hari } \\
(10 \text { days })\end{array}$ & $\begin{array}{c}20 \text {-hari } \\
(20 \text { days })\end{array}$ & $\begin{array}{c}30 \text {-hari } \\
(30 \text { days })\end{array}$ & $\begin{array}{c}\text { 40-hari } \\
(40 \text { days })\end{array}$ & $\begin{array}{c}\text { Rerata } \\
\text { (average) }\end{array}$ \\
\hline Tanpa inokulum (without inoculum) & 89,51 & 185,31 & 295,81 & 344,06 & $228,67^{\mathrm{c}}$ \\
\hline $\begin{array}{l}\text { Inokulum cairan rumen (with inoculum of } \\
\text { rumen liquid) }\end{array}$ & 180,36 & 268,68 & 339,12 & 397,97 & $229,65^{\mathrm{b}}$ \\
\hline $\begin{array}{l}\text { Inokulum lumpur gambut (with inoculum of } \\
\text { peat } m u d \text { ) }\end{array}$ & 242,33 & 297,93 & 405,53 & 487,27 & $358,25^{\mathrm{a}}$ \\
\hline Rerata (average) & $170,73^{\mathrm{s}}$ & $250,64^{\mathrm{r}}$ & $346,82^{\mathrm{q}}$ & $409,77^{\mathrm{p}}$ & \\
\hline
\end{tabular}

a,b,c Superskrip yang berbeda pada kolom yang sama menunjukkan perbedaan $(\mathrm{P}<0,05)($ different superscripts at the same column indicate significant differences $(P<0.05))$.

${ }^{\mathrm{p}, \mathrm{q}, \mathrm{r}, \mathrm{s}}$ Superskrip yang berbeda pada baris yang sama menunjukkan perbedaan $(\mathrm{P}<0,05)$ (different superscripts at the same row indicate significant differences $(P<0.05))$.

penambahan cairan rumen sebesar 229,65 $\mathrm{ml}$ dan tanpa inokulum sebesar $228,67 \mathrm{ml}$, tetapi volume biogás antara penambahan cairan rumen dengan tanpa inokulum tidak memiliki perbedaan nyata. Hal ini menunjukkan bahwa banyak terkandung bahan organik yang mudah tercerna pada perlakuan penambahan inokulum lumpur gambut daripada perlakuan penambahan inokulum cairan rumen dan tanpa inokulum. Perbedaan kecernaan dapat disebabkan perbedaan koloni mikrobia yang terkandung di dalam digester. Produksi gas merupakan hasil proses fermentasi yang terjadi di dalam rumen yang dapat menggambarkan banyaknya bahan organik yang tercerna (Ella et al., 1997). Perbedaan nilai kecernaan disebabkan variasi total koloni mikrobia (Sudirman, 2005). Volume biogás yang dihasilkan semakin meningkat erat kaitannya dengan ketersediaan bahan organik yang mudah dicerna dan kondisi bakteri yang sudah beradaptasi dengan lingkungan digester. Pada $\mathrm{pH}$ rendah dekomposisi bahan organik dilakukan oleh bakteri yang dapat hidup pada $\mathrm{pH}$ rendah dan dekomposisi yang dihasilkan tidak optimal karena bakteri bekerja baik pada kondisi $\mathrm{pH}$ netral. Menurut Cronin dan Lo (1998), dekomposisi bahan organik yang berasal dari feses ternak mulai menghasilkan biogas setelah fermentasi berlangsung selama sepuluh hari dan sering terjadi lebih lambat lagi sampai hari kelima belas. Volume gas metan rata-rata meningkat dari 0,08-0,19 L CH4/hari dan penurunan hydraulic 
retention times (HRT) dari 5-3 hari. Hasil ini lebih rendah bila dibandingkan dengan Baloch et al. (2007), yang menyatakan bahwa produksi gas meningkat dengan menurunkan cemaran organik, yaitu biogas meningkat berkisar 16-62 L CH4/hari.

\section{Kadar metan biogas}

Rerata kadar metan biogas pada tiap digester dengan beda perlakuan dan pengamatan setiap 10 hari, masing-masing disajikan pada Tabel 5.

Kadar metan yang dihasilkan lebih tinggi (mencapai 53\%) dengan volume $\pm 405,5 \mathrm{ml}$ dalam waktu 40 hari, hal ini menunjukkan bahwa penambahan limbah cairan rumen memberikan dampak positif terhadap pembentukan biogas maupun kadar gas metan, sehingga penambahan limbah cairan rumen mendorong selektivitas ke arah pembentukan gas metan, jika dikondisikan sesuai kebutuhan untuk tumbuh kembang bakteri rumen seperti perlunya kondisi aklimatisasi yang sesuai untuk tumbuh kembang bakteri dan proses adaptasi pada perlakuan selanjutnya. Temperatur dalam rumen adalah antara 38 sampai $42^{\circ} \mathrm{C}$ dengan $\mathrm{pH} 6,8$ di dalam perut ternak ruminansia (Adger dan Brown, 1995).

Kelebihan substrat yang diumpankan ke dalam bioreaktor, menyebabkan bakteri acidogen dan acetogen semakin aktif dan semakin cepat tumbuh, sehingga semakin banyak bahan organik (karbohidrat, protein dan lemak) dikonversi menjadi asam lemak yang menyebabkan menurunnya $\mathrm{pH}$. Bakteri metanogen tidak dapat bekerja secara optimal pada $\mathrm{pH}$ yg rendah. Hal ini menyebabkan ketidakseimbangan antara acidogenesis dan metanogenesis karena proses didominasi oleh proses acidogenic dan aktivitas metanogenesis kurang baik di dalam sistem.

\section{Produksi metan}

Rerata produksi metan pada tiap digester dengan beda perlakuan dan pengamatan setiap 10 hari, disajikan pada Tabel 6.

Produksi gas metan yang dihasilkan tinggi. Hal ini menunjukkan bahwa penambahan lumpur gambut dan limbah cairan rumen memberikan dampak positif terhadap pembentukan biogas maupun kadar gas metan. Semakin lama waktu fermentasi menunjukkan terjadi peningkatan produksi metan yang dihasilkan. Hal ini disebabkan semakin lama bakteri yang tinggal di dalam digester maka bakteri sudah beradaptasi dalam lingkungan digester, sehingga bila nutrien yang ada dalam digester masih ada maka pertumbuhan bakteri pembentuk metan masih berjalan dan produksi metan masih dapat berlangsung. Menurut Barlaz (1996), fase dekomposisi dan pembentukan metan ada empat yaitu fase aerobik, fase asam anaerobik, fase peningkatan produksi metan, dan fase

Tabel 5. Nilai kadar metan pada produksi biogas (\%) (methan value on biogás production (\%))

\begin{tabular}{lccccc}
\hline \hline \multicolumn{1}{c}{ Perlakuan (treatment) } & $\begin{array}{c}\text { 10-hari } \\
(10 \text { days })\end{array}$ & $\begin{array}{c}20 \text {-hari } \\
(20 \text { days })\end{array}$ & $\begin{array}{c}30 \text {-hari } \\
(30 \text { days })\end{array}$ & $\begin{array}{c}40 \text {-hari } \\
(40 \text { days })\end{array}$ & $\begin{array}{c}\text { Rerata } \\
\text { (average }^{\text {ns }}\end{array}$ \\
\hline $\begin{array}{l}\text { Tanpa inokulum (without inoculum) } \\
\begin{array}{l}\text { Inokulum cairan rumen (with inoculum of rumen } \\
\text { liquid) }\end{array}\end{array}$ & 11,75 & 34,28 & 41,22 & 46,41 & 35,91 \\
$\begin{array}{l}\text { Inokulum lumpur gambut (with inoculum of peat } \\
\text { mud) }\end{array}$ & 15,09 & 28,58 & 48,87 & 53,67 & 35,74 \\
\hline Rerata (average) & $16,22^{\mathrm{s}}$ & $33,88^{\mathrm{r}}$ & $45,47^{\mathrm{q}}$ & $51,32^{\mathrm{p}}$ & \\
\hline
\end{tabular}

${ }^{\mathrm{p}, \mathrm{q}, \mathrm{r}, \mathrm{s}}$ Superskrip yang berbeda pada baris yang sama menunjukkan perbedaan $(\mathrm{P}<0,05)($ different superscripts at the same row indicate significant differences $(P<0.05))$.

ns non significant.

Tabel 6. Nilai produksi metan pada biogas ( $\mathrm{ml})$ (methane production value on biogas $(\mathrm{ml})$ )

\begin{tabular}{|c|c|c|c|c|c|}
\hline Perlakuan (treatment) & $\begin{array}{l}\text { 10-hari } \\
(10 \text { days })\end{array}$ & $\begin{array}{c}20 \text {-hari } \\
(20 \text { days })\end{array}$ & $\begin{array}{c}\text { 30-hari } \\
(30 \text { days })\end{array}$ & $\begin{array}{c}\text { 40-hari } \\
(40 \text { days })\end{array}$ & $\begin{array}{c}\text { Rerata } \\
\text { (average) }\end{array}$ \\
\hline Tanpa inokulum (without inoculum) & 19,47 & 63,52 & 121,93 & 159,68 & $91,15^{\mathrm{c}}$ \\
\hline $\begin{array}{l}\text { Inokulum cairan rumen (with inoculum of rumen } \\
\text { liquid) }\end{array}$ & 21,35 & 76,79 & 165,73 & 213,59 & $119,36^{\mathrm{b}}$ \\
\hline $\begin{array}{l}\text { Inokulum lumpur gambut (with inoculum of peat } \\
\text { mud) }\end{array}$ & 36,57 & 115,57 & 187,84 & 262,49 & $150,62^{\mathrm{a}}$ \\
\hline Rerata (average) & $25,79^{\mathrm{s}}$ & $85,29^{\mathrm{r}}$ & $158,5^{\mathrm{q}}$ & $211,92^{\mathrm{p}}$ & \\
\hline
\end{tabular}


penurunan pembentuk metan. Pada fase aerobik, oksigen dikonsumsi untuk menghasilkan gula terlarut sebagai sumber karbon, dan hampir 100\% dihasilkan gas $\mathrm{CO}_{2}$. Fase asam anaerobik dimulai saat oksigen dan nitrat menurun, ditandai dengan dihasilkannya asam karboksilat secara cepat dan penurunan nilai $\mathrm{pH}$ di bawah 6,0 . Konsentrasi $\mathrm{CO}_{2}$ tinggi dan dihasilkan juga $\mathrm{H}_{2}$ sebagai produk dari aktifitas fermentasi gula. Fase ketiga ditandai dengan produksi metan meningkat sampai batas maksimal konsentrasinya menjadi $50-70 \%$ dengan diimbangi $\mathrm{CO} 2$, asam karboksilat menurun, $\mathrm{pH}$ meningkat dan populasi asetogenik meningkat. Fase keempat ditandai dengan menurunnya produksi metan dan konsentrasinya relatif konstan yaitu sekitar $60 \%$, konsentrasi asam karboksilat menurun hingga di bawah $100 \mathrm{mg} / 1$.

\section{Kesimpulan}

Kesimpulan penelitian yaitu penambahan lumpur gambut menunjukkan efisiensi dalam pembentukan metan. Penambahan limbah cairan rumen dan lumpur gambut sebesar $25 \%$ dari jumlah substrat yang diisikan ke dalam fermentor sebagai inokulum dapat meningkatkan volume gas, kadar metan dan produksi metan dalam biogas.

\section{Daftar Pustaka}

Adger, N.E. and K. Brown. 1995. Land Use and the Causes of Global Warming. John Wiley and Sons, New York. pp. 96-111.

Arora, S.P. 1992. Pencernaan Mikrobia pada Ruminansia. Gadjah Mada University Press. Yogyakarta.

Asenjo, J.A., W.H. Sund, and J.L. Spencer. 1986. Optimalization of batch processes involving simultanius enzimatic and microbial reaction. J. Biotech. Bioengine. 37: 1074-1087.

Astuti, M. 1981. Rancangan Percobaan dan Analisis Statistik. Fakultas Peternakan. Universitas Gadjah Mada. Yogyakarta.

Baloch, M.I., J.C. Akunna, and P.J. Collier. 2007. The performance of a phase separated granular bed bioreactor treating brewery wastewater. J. Biores. Technol. 98: 18491855.

Barlaz, M.A. 1996. Microbiology of solid waste landfills. In: Microbiology of Solid Waste. Edited by Palmisano, A.C. and M.A. Barlaz. CRC press, Inc. Boca Raton, Florida, USA.
Blakely, J. dan D.H. Bade. 1991. Ilmu Peternakan. Diterjemahkan B. Srigandono. Gadjah Mada University Press. Yogyakarta.

Chae, K.J., A. Jang, S.K. Yim, and I.S. Kim. 2007. The effects of digestion temperature and temperature shock on the biogas yields from the mesophilic anaerobic digestion of swine manure. J. Biores. Technol. 99: 1-6.

Cicerone, R.J. and R.S. Oremland. 1988. Biogeochemical aspects of atmospherie metane. Global Biochem. Cyc. 2: 299-327.

Cronin, C. and K.V. Lo. 1998. Anaerobic treatment of brewery wastewater using UASB reactors seeded with activated sludge. J. Biores. Technol. 64: 33-38.

Eckenfelder, W. 2000. Industrial Water Pollution Control. McGraw Hill. Singapore.

Ella, A.S., Hardjosoewigyo, T.R. Wiradaryadan, dan M. Winugroho. 1997. Pengukuran Produksi Gas dari Hasil Proses Fermentasi Beberapa Jenis Leguminosa Pakan Prosiding Seminar Nasional II. NMT. Fakultas Peternakan IPB. Bogor.

Gallert, C. and J. Winter. 1999. Bacterial Metabolism in Wastewater Treatment Systems. Environmental Processes I. Weinheim : WILEY-VCH Verlag GmbH \& Co. KgaA.

Hidayat, I. 2005. Pengaruh $\mathrm{pH}$ terhadap Aktivitas Endo-1,4- $\beta$-Glucanose Bacillus sp. AR 009. Biodiversitas. 6(4): 244-246.

Lynd, L.R., P.J. Weimer, W.H. van Zyl, and I.S. Pretorius. 2002. Microbial cellulose utilization : fundamentals and biotechnology. Microbiol. Mol. Biol. Rev. 66(3): 506-577.

Omed, H.M., D.K. Lovettand, R., and F.E. Axford. 2000. Faeces as A Source of Microbial Enzymes for Estimating Digestibility. In: Forage Evaluation in Ruminant Nutrition, D.I. Givens, E. Owen, R.F.E. Axford dan H.M. Omed (Eds). CABI Publising. New York. Pp: 135-150.

Simamora, S. dan Salundik. 2006. Meningkatkan Kualitas Kompos. Cetakan Pertama. Agromedia Pustaka. Jakarta.

Stams, A., S.J.W.H. Oude Elferink, and P. Westermann. 2003. Metabolic interactions between metanogenic consortia and anaerobic respiring bacteria. In Scheper (ed): Advances in Biochemical Engineering/ Biotechnology, Vol. 81. Springer-Verlag, Berlin, pp. 31-56. 
Sudaryanto. 2002. Pengembangan Bioetanol di Indonesia. Penebar Swadaya. Jakarta.

Sudirman. 2005. Validasi dan kajian faktor-faktor yang mempengaruhi efikasi penggunaan feses sebagai pengganti cairan rumen dan penetapan kecernaan in vitro di daerah tropik. Disertasi program doktor pascasarjana. Universitas Gadjah Madam Yogyakarta.
Yusiati, L.M. 2011. Global Warming, Methan dan Peternakan. Pidato Pengukuhan Jabatan Guru Besar pada Fakultas Peternakan. Universitas Gadjah Mada. Yogyakarta.

Yuwono, D. 2006. Kompos. Penerbit Penebar Swadaya. Jakarta. 